\title{
Experiment and Economic Analysis of an Air/Molten Salt Direct-Contact Heat Exchanger
}

Mark S. Bohn

August 1983

To be presented at the Physical and Chemical

Energy Storage Annual Contractors' Review Meeting Arlington, Virginia

12-14 September 1983

Prepared under Task No. 1298.12

WPA No. 348-83

Solar Energy Research Institute

A Division of Midwest Research Institute

1617 Cole Boulevard

Golden, Colorado 80401

Prepared for the

U.S. Department of Energy

Contract No. EG-77-C-01-4042 


\section{NOTICE}

This report was prepared as an account of work sponsored by the United States Government. Neither the United States nor the United States Department of Energy, nor any of their employees, nor any of their contractors, subcontractors, or their employees, makes any warranty, express or implied, or assumes any legal liability or responsibility for the accuracy, completeness or usefulness of any information, apparatus, product or process disclosed, or represents that its use would not infringe privately owned rights. 


\title{
EXPERTMENT AND ECONOMIC ANALYSIS OF AN ATR/HOLTEN SALT DIRECT-CONTACT HRAT EXCBANGER
}

\author{
Mark S. Bohn \\ Solar Energy Research Institute \\ Golden, Colorado 80401
}

\begin{abstract}
Direct-contact heat exchange (DCHX) has several advantages over conventional finned-tube heat exchangers. Without the intervening tube wall, the rmal resistance is lower and fouling of the heat-exchange surface is not a problem. Intimate mixing of the two fluid streams can produce very high rates of heat transfer. The heat exchanger design can be simpler, require less construction material, and provide more flexibility in choice of materials.
\end{abstract}

\section{BOMENCLATURE}

$C_{p}$ air specific heat $\left(\mathrm{J} / \mathrm{kg}{ }^{\circ} \mathrm{C}\right)$

$\mathrm{C}_{\text {s }}$ salt specific heat, 1iquid ( J/kg ${ }^{\circ} \mathrm{C}$ )

$\dot{\mathrm{m}}_{\mathrm{a}}$ air flow rate $(\mathrm{kg} / \mathrm{hr})$

$\dot{\mathrm{m}}_{\mathrm{s}}$ salt flow rate (kg/hr)

$Q_{a}$ rate of heat transier to the air (W)

$Q_{S} \quad$ rate of heat transfer from the salt (W)

$\mathrm{T}_{\mathrm{ai}}$ air inlet temperature $\left({ }^{\circ} \mathrm{C}\right)$

$\mathrm{T}_{\text {ao }}$ air outlet temperatire $\left({ }^{\circ} \mathrm{C}\right)$

$T_{\text {si }}$ salt inlet temperature $\left({ }^{\circ} \mathrm{C}\right)$

$\mathrm{T}_{\text {so }}$ salt outlet temperature $\left({ }^{\circ} \mathrm{C}\right)$

Ua overąll volumetrac heat transfer coefficient $\left(\mathrm{W} / \mathrm{m}^{30} \mathrm{C}\right)$

$v_{p} \quad$ volume of packing $\left(m^{3}\right)$

$\Delta T_{\mathrm{a}} \quad \log$ mean temperature difference $\left({ }^{\circ} \mathrm{C}\right)$

\section{LNTRODUCTION}

The DCHX consists of a column substantially filled with a packing material. The packing material consists of rings or saddles that are generally two or three inches in size for large columns and are dumped in the column in a random arrangement. One fluid is introduced at the top of the vessel and flows downward; the other is introduced at the bottom of the vessel and flows in a countercurrent up through the vessel. By properly distributing the liquid at the top of the packing, the flow occurs in the form of many small rivulets flowing over the packing. The packing increases the surface area between the two phases and increases the time during which the liquid stream is exposed to the gas greatly increasing the rate of heat transfer per unit volume of heat exchanger.

DCHX is especially attractive in applications in which it is necessary to transfer heat between a gas and a liquid because large rates of heat transfer can be achieved without the added expense of finned tubes. Among solar thermal technologies, two examples include high-temperature process air and the Brayton cycle (Fig. 1). In both examples, solar energy provides a heat source at a central receiver in which molten salt cools the receiver, thereby transferring the solar energy to a storage device. Molten salt is the logical heat transfer fluid at high temperatures because it exhibits very low vapor pressure, high sensible heat storage, excellent heat transfer characteristics, and because it is relatively benign toward receiver containment materials (at temperatures below $600^{\circ} \mathrm{C}$ for state-of-the-art salts).

In either concept, it is necessary to transfer heat from the molten salt to air. Conventional heat-exchange technology for transferring this heat would be a finned-tube heat exchanger. The molten salt is pumped through the tubes and air is pumped over the finned outside surface of the tubes. In the DCXX concept, molten salt would be introduced at the top of a packed column and the air would be blown up through the bottom of the column.

Because of the lack of heat transfer data or design correlations, it is not possible at this time to accurately assess the economic potential of direct-contact heat exchange. Such an assesment requires us to determine the rate of heat transfer per unit volume in the DCHX. This determines the required size (and therefore cost) of the column that must deliver the required amount of heat to the air. It also determines the costs associated with operating the equifment-opimarily, the cost of blowing the air through the column.

It is possible to use mass transfer data by assuming that the mass transfer-heat transier analogy is valid [1]. However, there are a number of reasons to suspect this approach, and, therefore, an experimental determination of the heat :ransfer coefificients is advisable. 


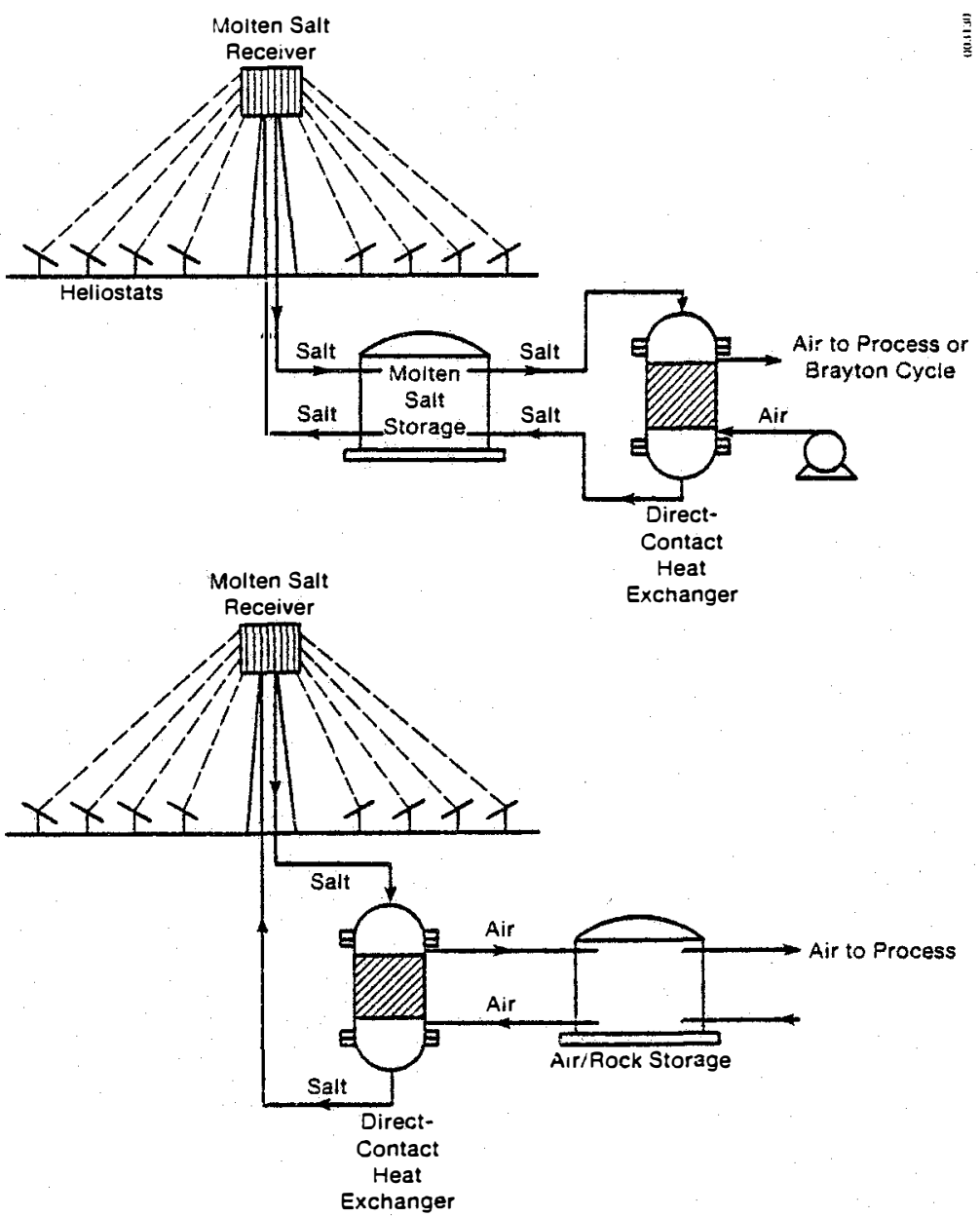

F1gure 1. Applications for DHrect-Contact Beat Rrchangers

The objective of the present work is threefold: (i) the experimental determination of heattransfer coefficients in direct-contact heat exchange between molten salt and air, (ii) the calculation of these heat-transfer coefficients based on the mass transfer analogy and comparison with the experimental data, and (iii) an economic analysis using the experimental data and comparing DCHX with conventional finned-tube heat exchangers. In general, the objective of the present work is to deteral ne if, and in what applications, DCHX is a cost-effective technology. This paper describes the experimental apparatus, methods, and the results that are compared with the calculated values. Then, results of an economic analysis are presented that compare the cost-effectiveness of DCHX and finned-tube heat exchangers in several applications. For a more detailed treatment of this subject, the reader is referred to Bohn (1983).
EXPERDERTAL MRASURENTXTS OF VOLINETRIC HRAT IRANSFER COEFFICIENTS

\section{Description of the Apparatus}

A flow diagram of the experimental apparatus is given in Fig. 2, and a detailed diagram of the packed column is shown in Fig. 3. The test loop is a batch operation, with regulated air pressure on the upper tank providing regulated salt flow through the salt valve. The upper tank is filled with molten salt and pressurized to approximately $1 / 2$ atm. gauge. In this way, the salt flow is affected minimally by the loss of salt head in the upper tank. The salt flows through the salt valve into the top of the column and into a distributor that provides uniform salt flow onto the top of the packing. The packing bed is supported by a gas injection support plate that allows the salt to flow 


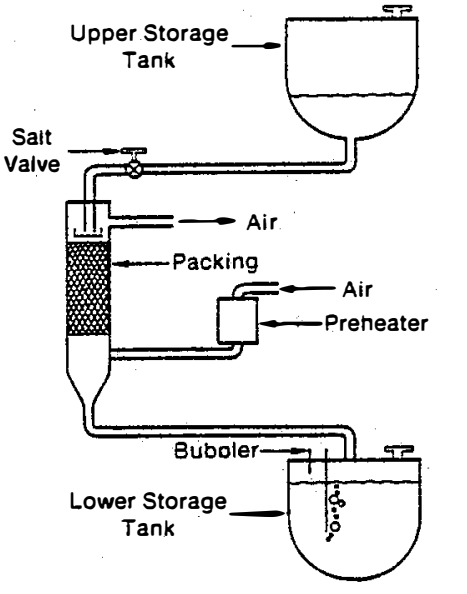

Figure 2. Flov Dhagram of a Drect-Contact Beat Erchanger Test Loop

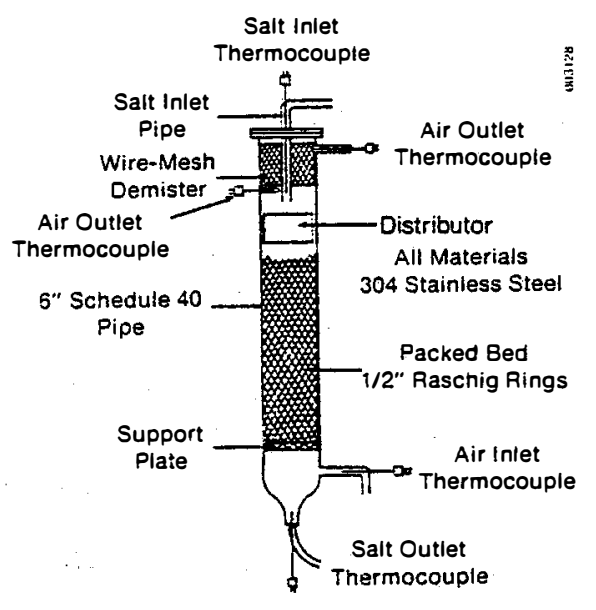

Figure 3. Detalls of the Packed Column

downward while providing a uniform air distribution at the bottom of the packing. After the air passes up through the bed, it flows around the annular gap between the salt distributor and the column's inside diameter. The air then flows through a wire mesh demister that removes any small salt droplets before the air flows out of the column. Salt flowing out of the bottom of the bed is collected at the bottom of the column and flows to the lower salt tank.

The column size used in this experiment was quite typical of those in pilot-scale studies. Details of the column design, including size, distributors, bed height, packing size, etc., were chosen with the assistance of Norton Chemical Company, Rolling Meadows, Illinois. The entire test loop, with the exception of the salt valve, was constructed of 304 stainless steel. The salt valve was made of 316 stainless steel.

Alr supplied at the bottom of the column was preheated by a 9-kw electric preheater powered by an SCR (silicon-controlled rectifier) power supply.
A proportional-integral process controller supplies the control signal to the SCR power supply based on the desired air temperature and the measured air temperature at the preheater outlet. A twocylinder, oil-free, 10-hp compressor supplies air to the preheater.

\section{Instrmentation}

The air flow rate was measured by an inline mass flow transducer manufactured by Datametrics, Inc. The salt flow rate was determined by a bubbler system that continuously monitored the level of salt in the lower salt tank. The lower tank volume was calibrated by filling it with water in 5-liter increments and recording the bubbler voltage output.

All thermocouples were Chrome1-Alume 1 (type K). Salt inlet temperature was determfned by a probe inserted into the vertical portion of the pipe from the upper tank. This probe should be a very good measure of salt inlet temperature since it is totally immersed in salt just before it flows into the salt distributor. This temperature was typically within $2^{\circ} \mathrm{C}$ of the upper-tank salt temperature. Salt outlet temperature was deternined by a probe inserted in the pipe leading out of the bottom of the column. The probe was inserted just to the point where the cone at the bottom of the column begins to expand. The probe was exposed to rivulets dripping from the packing support plate and is the best compromise for measuring salt outlet temperature. Constraints on this measurement include the trace heating on the column wall, which could affect the temperature of salt flowing along the wall, and air entering the column at a lower temperature than the salt leaving the column, which could reduce the outlet salt temperature reading if the probe were inserted further into the column. The response of this probe to sudden changes in the salt flow, air flow, and air inlet temperature suggests that the probe gives a good indication of salt outlet temperature. Air inlet temperature was determined by a probe inserted into the horizontal portion of the air inlet pipe and sensed the temperature of the air about $20 \mathrm{~cm}$ from the column. Air outlet temperature was determined by a probe inserted through the column just below the demister. Secondary measurements included uppertank salt and surface temperatures, lower tank surface temperature, colum surface temperature, bed temperature, and the pressure differential between the preheater outlet pipe and the column air outlet pipe.

Data were recorded by a Hewlett-Packard Model 85 computer which gave printed, displayed, and plotted information. A Leeds and Northrup strip chart also recorded surface temperatures, air flow rate, and bubbler output. Maximum air flow rates should generate operation near the loading point $(\Delta p=1.5$ in. $/ f t)$.

The maximum operating temperature of $350^{\circ} \mathrm{C}$ was chosen because conmon nitrate salts do not cause excessive corrosion with stainless sceel alloys at that temperature. From what is known about materials compatibility, adequate operating time could be expected from the apparatus if operation were limited to $350^{\circ} \mathrm{C}$. 
The heat tracing required to bring the loop initially up to operating temperature and to maintain this temperature was high-temperature tracing supplied by Nelson Electric. The tracing consisted of a stainless shell with nichrome wire inside, insulated from the shell with a refractory insulation. Approximately $50 \mathrm{~m}$ of the heat tracing was required to provide adequate heating. The test loop was then insulated with Johns-Manville Cerawool blanket to a thickness of approximately $15 \mathrm{~cm}$.

\section{Heat Transfer Measurements and Procedures}

Using the inlet and outlet salt and air temperatures and the salt and air flow rates, the rate of heat transfer can be determined from

$$
\begin{aligned}
& Q_{s}=\dot{\mathrm{m}}_{s} C_{s}\left(T_{s i}-T_{s o}\right) \\
& Q_{a}=\dot{m}_{a} C_{p}\left(T_{a O}-T_{a 1}\right) .
\end{aligned}
$$

Eq. (1) gives the rate of heat transfer from the salt and Eq. (2) gives the rate of heat transfer to the air. A comparison of $Q_{s}$ and $Q_{g}$ gives a quantitative measure of the quality of the heat transfer data since, in the absence of heat losses and measurement errors, $Q_{s}=Q_{a}$. We will, therefore, refer to the absolute value of the quantity 100(1$\left.{ }_{s} / Q_{a}\right) \%$ as the heat balance for the experiment.

The volumetric heat transfer coefficient can then be calculated from

$$
U_{a}=\frac{Q}{V_{p} \Delta T_{\text {m }}},
$$

where $V_{p}$ is the volume of the packing $\left(0.0167 \mathrm{~m}^{3}\right)$ and $\Delta \mathrm{T}_{\mathrm{m}}$ is the log-mean temperature difference:

$$
\Delta T_{\text {m }}=\frac{\left(T_{s i}-T_{a 0}\right)-\left(T_{s o}-T_{a i}\right)}{\ln \left(\frac{T_{s i}-T_{a 0}}{T_{s 0}-T_{a i}}\right)} .
$$

The value of $Q$ in Eq. (3) can be either $Q_{s}$ or $Q_{a}$; the error in Ua is, therefore, also the heat balance for the experiment.

Experimentally, it was possible to vary the salt flow rate, the air flow rate, and the salt and air inlet temperatures. The last two variables are of secondary importance (as long as the air inlet temperature is above the salt freezing point) and were, therefore, not varied in any systematic way. The salt flow rate was varied from 50 to $200 \mathrm{~kg} / \mathrm{hr}$ and the air flow was varied from 30 to $50 \mathrm{~kg} / \mathrm{hr}$. Higher salt flow rates could be attained, but this would have resulted in run times too short to establish steady conditions--a crucial requirement for good data (i.e. small values of the neat balance). Air flow rates much larger than $50 \mathrm{~kg} / \mathrm{hr}$ would produce column flooding.

The system was maintained at operating temperature continuously for about six months, with the exception of downtige for repairs. To minimize the time required to reach steady state, the heat trace was set so that the bed temperature was fairly close to the upper-tani salt temperature. Pressure was applied to the upper tank from the regulated air supply and the salt valve was opened. Achieving constant salt flow rate, as indicated by the bubbler output trace, generally required 20 minutes. Air flow could then be set to the desired value (1t was helpful to heat the preheater to about $200^{\circ} \mathrm{C}$ before turning on the air), and when steady state was achieved, the air flow could be adjusted to a new setting. An examination of the data indicated that the best heat balances were achieved when the salt flow was the most uniform and when no adjustments of the salt valve or tank pressure were necessary.

\section{Results and Discussion}

Experimental data are presented in Fig. 4 in the form of volumetric heat transfer coefficient versus air flow rate with salt flow as a parameter, in addition to calculated values based on the mass transfer analogy. The data are also shown in Table 1 , with heat transfer coefficients calculated from the mass transfer analogy.

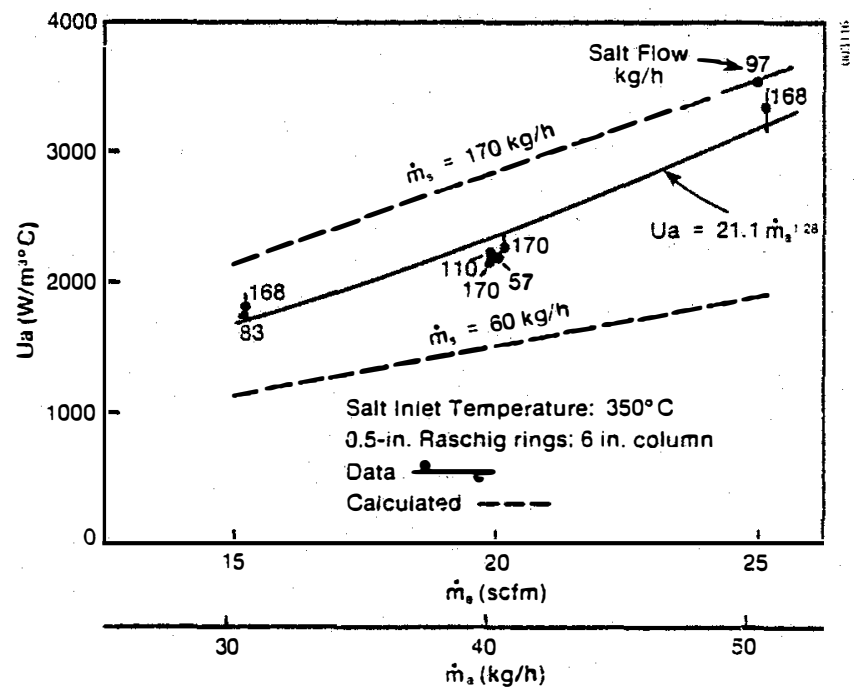

F1gure 4. Overall Volumetric Beat Transfer Coefficients Based on Experimental Data

The experimental heat transfer coefficients do not appear to depend on salt flow zate, because all the data for $\mathrm{m}_{\mathrm{a}} \approx 40 \mathrm{~kg} / \mathrm{hr}$ and for $57 \leqslant \dot{m}_{\mathrm{s}} \leqslant 170$ vary by only a few percentage points. The variation with air flow is relatively strong--a best fit produces

$$
\mathrm{Ua}=21.1 \dot{\mathrm{m}}_{\mathrm{a}} 1.28,
$$

where $m_{a}$ is in $\mathrm{kg} / \mathrm{hr}$ and $U a$ is in $\mathrm{W} / \mathrm{m}^{3}{ }^{\circ} \mathrm{C}$.

As shown in the last column of Table 1 , heat transfer coefficients calculated from mass transfer data underestimate neasured heat transfer coefficients, except at large salt flows. Overall heat transfer coefficients calculated from mass transfer data are shown in Fig. 4 for two salt flow rates, 170 and $60 \mathrm{~kg} / \mathrm{hr}$. These results further demon- 
Table 1. Heat Transfer Data and Comparison with Mass Transfer Calculations

\begin{tabular}{cccccc}
\hline $\begin{array}{c}\text { Salt Inlet } \\
\text { Temperature } \\
\left({ }^{\circ} \mathrm{C}\right)\end{array}$ & $\begin{array}{c}\text { Alr Flow } \\
(\mathrm{kg} / \mathrm{hr})\end{array}$ & $\begin{array}{c}\text { Salt Flow } \\
(\mathrm{kg} / \mathrm{hr})\end{array}$ & $\begin{array}{c}\text { Measured } \\
\left(\mathrm{W} / \mathrm{m}^{\left.3{ }^{\mathrm{Ua}}{ }^{\circ} \mathrm{C}\right)}\right.\end{array}$ & $\begin{array}{c}\text { Heat } \\
\text { Balance }\end{array}$ & $\begin{array}{c}\text { Calculated } \\
\text { Ua } \\
\left(\mathrm{W} / \mathrm{m}^{3}{ }^{\circ} \mathrm{C}\right)\end{array}$ \\
\hline 342 & 30.8 & 168 & 1820 & $\pm 3 \%$ & 2171 \\
348 & 30.9 & 83 & 1771 & 2 & 1429 \\
341 & 40.7 & 171 & 2252 & 6 & 2896 \\
353 & 40.5 & 57 & 2203 & 3 & 1478 \\
349 & 40.3 & 170 & 2164 & 4 & 2854 \\
348 & 40.2 & 110 & 2228 & 1 & 2189 \\
348 & 50.5 & 96 & 3520 & 5 & 2535 \\
342 & 50.9 & 168 & 3351 & 5 & 3574 \\
\hline
\end{tabular}

strate the lack of sensitivity to salt flow rate of the heat transfer data compared with the mass transfer data.

Overall system pressure drop is plotted in Fig. 5. Recall that this is a measure of the differential pressure from the column air inlet pipe to the colum air outlet pipe. Therefore, it includes not only pressure drop across the bed, but expansion and contraction losses at the column inlet and column outlet, and loss across the air distributor, salt distributor, and demister. Additional pressure-drop data were taken with zero salt flow to determine the contribution of all these column components. These data permit only a qualitative assessment of the bed pressure drop, however, because the bed pressure drop is only about $30 \%-40 \%$ of the measured system pressure drop. A satisfactory method of measuring bed pressure drop could not te found, because of the difficulty of isolating the high-temperature salt from a pressure sensing port or isolation diaphragm.

\section{ECONORIC ANALYSIS}

With experimental and theoretical values for the heat transfer coefficient, one can proceed to

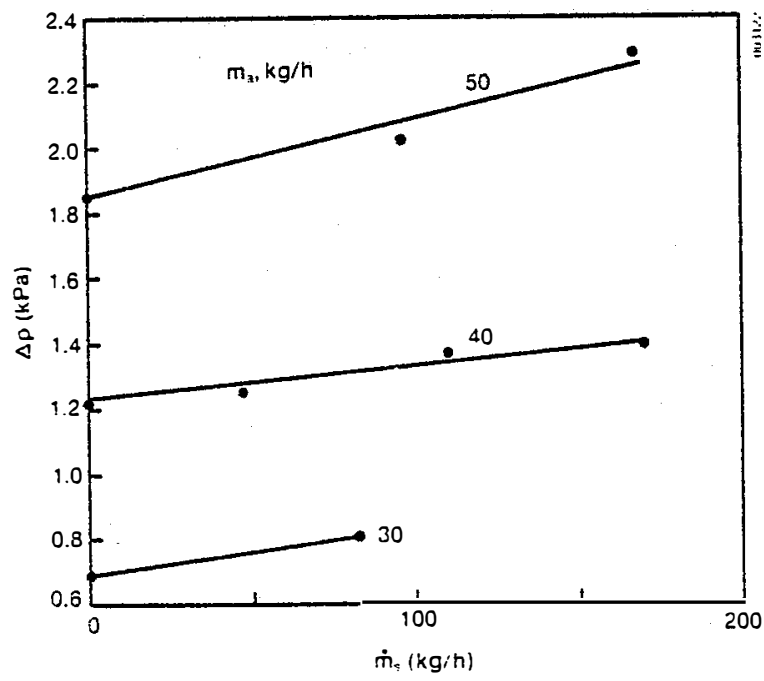

Figure 5. Overall System Pressure Drop determine the economic value of DCHX. Rather than basing economic calculations solely on the mass transfer data, actual heat transfer data should give us more confidence in the results. For several reasons, the experimental data cannot be applied directly to a commercial-size DCHX; therefore, even these results require some caution in interpretation.

\section{Yethod of the Analysis}

An economl c comparison of DCHX and finned-tube exchangers can be made by considering all capital and operating costs associated with the heat exchanger. The methodology (see Bohn 1983) then calculates the annual levelized cost. The annual levelized cost is the constant annual cost (In fixed dollars) which, if pald over the lifetime of the heat exchanger, would have a present value equal to the present value of the actual costs incurred over the lifetime of the heat exchanger. Because it computes one single cost, this method can take into account (1) escalation rates, (11) depreclation, (111) discount rates, (1v) lifetime, and (v) tax rates. This method, and values for parameters ( 1 ) through (v) used in the analysis, are described in Bohn (1983).

To determine capital cost, we must know the size of the heat exchanger and the materials of construction. The first is determined by the required heat duty, overall heat-exchange coefficlents, and $\log$-mean temperature differences. Materials of construction are deterulined by operatIng temperature and working fluids. For the sake of consistency, all capital costs have been determined from data given by Peters and Timerhaus (1980) for finned-tube heat exchangers and for packed towers.

For the finned-tube heat exchanger, we used the characteristics of the heat exchanger core denoted CF8.8 1.0J (A) by Kays and London (1964), which consists of $1-1 n$. o.d. tubes on 1.96-1n. spacing with spiral-wound fins--at 8.8 fins per inch and 0.012-in. fin thickness. Data on the core includes the colburn " $\mathrm{j}$ " factor (the heat transfer coefficlent on the air side) and the friction factor as a function of air-side Reynolds number. The salt-side Reyrolds number was designated a constant $(10,000)$ because the overall heat transfer coefficlent was not a strong function of the salt-side Reynolds number as long as the salt flow was turbu- 
lent. Also, salt-side pumping work is negligible, so salt-side pressure drop need be considered only from the standpoint of tube stress at elevated temperatures.

For the finned-tube heat exchanger, salt flows through the tubes and air flows across the finnedtube banks (crossflow arrangement). Given the flow rates (determined from the given heat duty and terminal temperatures) and the terminal temperatures, the heat exchanger's effectiveness is determined. Then, the required number of transfer units (NTU) is determined from equations for crossflow exchangers. Beginning with the lowest air-side Reynolds number for which the heat exchanger core data is given, the frontal area of the core is determined, the air-side heat transfer coefficient is calculated, the fin efficiencies are calculated, and the overall heat transfer coefficient is then determined. From NTU one may calculate the required total heat transfer surface required that determines the core dimension in the air-flow direction which also determines the core pressure drop. Af ter the surface area and pressure drop are obtained, the capital cost may be calculated. This procedure is repeated for increasing air-side Reynolds numbers until a minimum cost results. The heat exchanger core was restricted to the maximum heat transfer area for which cost data are presented in Peters and Timmerhaus (1980): $900 \mathrm{~m}^{2}$. This corresponds to a shell diameter of $2.77 \mathrm{~m}$ $(9.0 \mathrm{ft})$ for $4.87-\mathrm{m}(16-\mathrm{ft})$-long $2.54-\mathrm{cm}\left(1-i \mathrm{n}_{0}\right)-0 . \mathrm{d}$. tubes. Multiple heat exchangers are specified when heat duties require more than this maximum heat transfer area.

Optimization of the DCHX is somewhat different because of flonding constraints. Outlet air temperature cannot be specified a priori. Beginning with a colum diameter of $1 \mathrm{~m}$ (the smallest diameter for which cost data is available), the volume of packing is calculated. (The shortest practical column height, equal to the diameter, was used because this always minimized annual cost. Column diameters larger than the column height produce problems with uniform salt and air distribution in the column.) For an assumed value of the overall heat-transfer coefficient, the log-mean temperature is determined, and, therefore, the air outlet temperature is known. This determines the air flow rate; from the generalized pressure drop correlation, we may determine the pressure drop. Diameters that produce operating conditions off the generalized pressure drop map are rejected. A maximum column diameter of $5 \mathrm{~m}$ was used, since this is the largest for which Peters and Timmerhaus give cost data. The packing type used in the calculations was 2-inch stainless steel pall rings. With the column size and pressure drop, the annual cost may be calculated. The procedure is repeated for increasing colum diameters, giving annual cost as a function of approach temperature (air outlet temperature). The overall volumetric heat transfer is taken as a parameter; the values $\mathrm{Ua}=2000,3000$, and $4000 \mathrm{~W} / \mathrm{m}^{3}{ }^{\circ} \mathrm{C}$ were used. We can then use the experimental values of $\mathrm{Ua}$, or the calculated values of $\mathrm{Ua}$, along with the results of this economic calculation (which will also give sensitivity to $\mathrm{Ua}$ ) to appraise the economic viability of DCHX relative to finned-tube heat exchangers.

Table 2 summarizes the assumed materials of construction for both types of heat exchangers used for the calculation as a function of salt inlet temperature. The assumed air inlet temperature is also given for the three salt temperatures that were run.

It will be necessary to perform heat-transfer experiments at full-scale to determine how the larger packing required for commercial-size columns performs relative to the 1/2-in. packing tested here before recommending DCKX for commercial application. In the absence of such full-scale data, we must rely on mass transfer data. Since extensive mass transfer data are avallable for aimost all packings (types and sizes), we can easily determine mass transfer coefficient dependence in packing size and type. Comparing the present heat transfer data with mass transfer calculations provides the only guidance to the applicability of the approach. For a detailed discussion of this compartson, see Bohn (1983).

Based on experimental data and corresponding heat transfer coefficients calculated from mass transfer data, an appropriate range of heattransfer coefficient $\forall a$ for the $1 / 2-1$. Raschig rings is $1800-3500 \mathrm{~N} / \mathrm{m}^{3}{ }^{\circ} \mathrm{C}$. It seems reasonable to perform the economic calculations based on a range

Table 2. Materials of Construction

\begin{tabular}{|c|c|c|c|}
\hline \multicolumn{2}{|c|}{ Temperatures } & \multirow{2}{*}{ DCHX } & \multirow{2}{*}{ Finned-Tube } \\
\hline Salt in & Air In & & \\
\hline $360^{\circ} \mathrm{C}$ & $200^{\circ} \mathrm{C}$ & $\begin{array}{l}\text { Stainless Pall rings in } \\
\text { an externally insulated } \\
\text { carbon-steel column }\end{array}$ & Carbon-steel tubes and fins \\
\hline $560^{\circ} \mathrm{C}$ & $250^{\circ} \mathrm{C}$ & $\begin{array}{l}\text { Stainless Pall rings in } \\
\text { an externally insulated } \\
\text { stainless column }\end{array}$ & Stainless tubes and fins \\
\hline $70^{\circ} \mathrm{C}$ & $550^{\circ} \mathrm{C}$ & $\begin{array}{l}99 \% \text { alumina saddles in } \\
\text { an internally insulated } \\
\text { carbon steel column with } \\
\text { Inconel liner }\end{array}$ & Incoloy 800 tubes and fins \\
\hline
\end{tabular}


of $\mathrm{Va}$ from $2000-4000 \mathrm{~W} / \mathrm{m}^{3}{ }^{\circ} \mathrm{C}$ for the commercialsize DCHX. One can then assess the sensitivity of the eocnomics on Ua until a full range of data at full scale is made available.

Results

Figures 6,7 , and 8 give the results of the economic analysis. Each figure gives the cost of transferring $1 \mathrm{GJ}$ of energy as a function of air outlet temperature. The graphs present results for 1 atm operating pressure. As the air outlet temperature approaches the salt inlet temperature, more surface area for the finned-tube heat exchanger is required and more volume of packing is required for the DCHX. This is because the logmean temperature difference (Eq. 4) is reduced and this increases the packing volume for a fixed heattransfer coefficient and heat duty (Eq. 3). This can be compensated by increasing the air flow to increase the heat-transfer coefficient, but this also increases operating costs.

Generally, DCHX provide closer temperature approaches than finned-tube exchangers before a rapid increase in cost results. The curves for the DCHX for given Ua increase for low outlet air temperature because the volumetric heat-transfer coefficient has been artifically fixed, and the only way to reduce outlet temperature is to increase air flow (which drives up . the cost). For $\mathrm{Ua}_{\mathrm{a}}=2000 \mathrm{~W} / \mathrm{m}^{3}{ }^{\circ} \mathrm{C}$, this is generally not seen for che temperature approaches presented, less than $30^{\circ} \mathrm{C}$.

Calculations for a higher operating pressure (5 atm, not given in graphical form) were for $5 \mathrm{MW}_{\mathrm{th}}$ or $2 \mathrm{MW}_{\mathrm{th}}$ heat duty, while those for 1 atm pressure were for $1 \mathrm{MW}_{\mathrm{th}}$. The higher-pressure units generally resulted in maximum-sized packed columns ( $5 \mathrm{~m} \times 5 \mathrm{~m}$ ). Larger columns can be built, but since cost data were restricted to a 5 m diameter, calculations were restricted to this diameter for consistency. Also, the finned-tube heat exchanger tended to reach maximum size $\left(900 \mathrm{~m}^{2}\right)$ before the DCHX. One major conclusion, then, is that DCHX provides substantially more heat transfer capacity per a given size of equipwent.

The cost advantage of $\mathrm{DCHX}$ relative to finnedtube heat exchangers is not a strong function of approach (difference between salt inlet and air outlet temperatures), except for small approaches where the finned-tube costs increase more rapidly. Table 3 gives the cost ratio from all six cases at a $10^{\circ} \mathrm{C}$ approach. The DCHX curve for $U_{a}=3000 \mathrm{~W} /$ $\mathrm{m}^{3}{ }^{\circ} \mathrm{C}$ was used in each case.

Table 3. Cost of Transferring Heat via DCHX Relative to Finned-Tube Beat Exchangers

\begin{tabular}{ccc}
\hline \multirow{2}{*}{ Temperature } & \multicolumn{2}{c}{ Operating Pressure } \\
\cline { 2 - 3 } & 1 atm & 5 atm \\
\hline $360^{\circ} \mathrm{C}$ & 0.44 & 0.46 \\
$560^{\circ} \mathrm{C}$ & 0.46 & 0.57 \\
$760^{\circ} \mathrm{C}$ & 0.18 & 0.26 \\
\hline
\end{tabular}

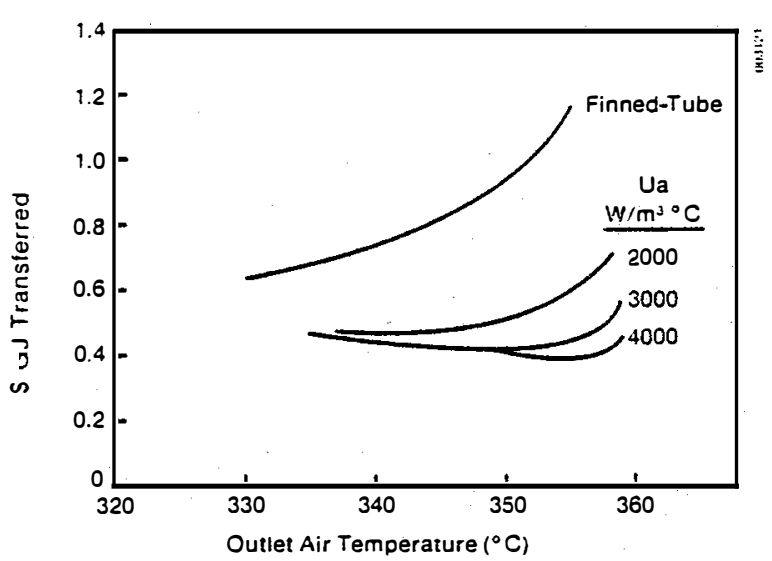

F1gure 6. Cost Comparison for $360^{\circ} \mathrm{C}, 1$ atse, $1 \mathrm{kth}_{\text {th }}$

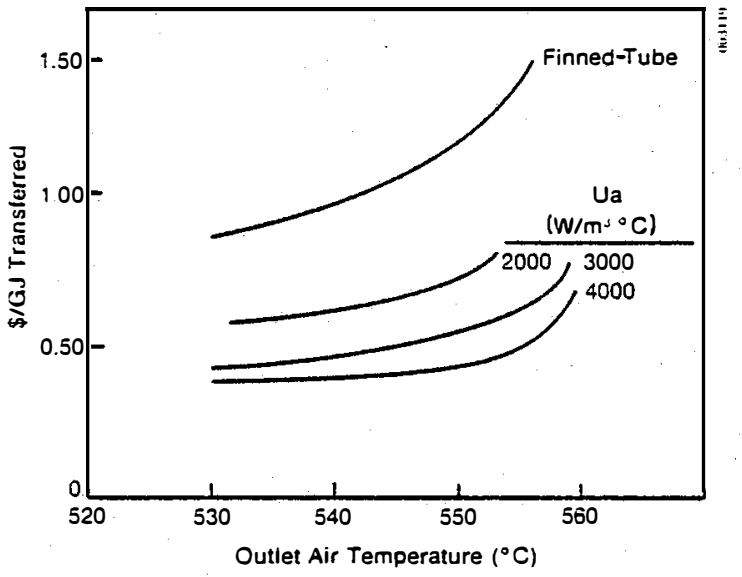

E1gure 7. Cost Comparison for $560^{\circ} \mathrm{C}, 1$ ata, $1 \mathrm{MH}_{\mathrm{th}}$

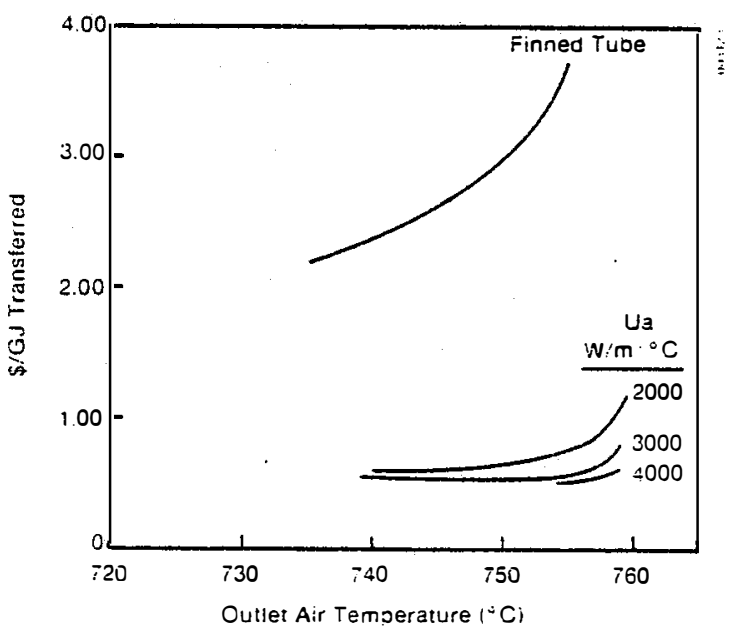

Figure 8. Cost Comparison for $760^{\circ} \mathrm{C}, 1 \mathrm{acm}, 1 \mathrm{Mw}_{\mathrm{th}}$ 
There appeared to be no large decrease in this ratio in going from $360^{\circ} \mathrm{C}$ to $560^{\circ} \mathrm{C}$, because the cost of construction materials increased substantially for both types of heat exchangers. If we used an Internally insulated carbon-steel column with stainless steel Pall rings for $560^{\circ} \mathrm{C}$, a significant improvement would result. (Since this represents a larger technical risk than the externally insulated stainless steel column, it is not a falr comparison with commercially available stainless-steel finned-tube heat exchangers.) The large reduction in relative cost in going from $560^{\circ} \mathrm{C}$ to $760^{\circ} \mathrm{C}$ is due to the avoldance of high alloys in the DCHX, while the finned-tube does require such materials of construction. Even though the highpurity alumina packing is more costly than a stainless-steel packing, using a carbon-steel column provides a very large cost advantage over the Incolloy finned-tube heat exchanger.

\section{Conclusions}

Volumetric heat-transfer coefficients in the range of $1800-3500 \mathrm{~W} / \mathrm{m}^{3}{ }^{\circ} \mathrm{C}$ were measured experimentally. The coefficlent depends on air flow rate but not on salt flow rate. Heat-transfer coefficients based on mass transfer data show dependence on both air flow and salt flow. Thus, the mechanisms controlling heat transfer differ from those controlling mass transfer.

The measured heat-transfer coefficlents are large enough so that direct-contact heat exchangers should be wuch more cost-effective than conventional finned-tube heat exchangers. At low to midtemperatures $\left(360^{\circ}-560^{\circ} \mathrm{C}\right)$, the levelized annual cost (capital and operating) ratio should be about one-half; at high temperatures $\left(>600^{\circ} \mathrm{C}\right)$, where high-alloy steels will be required in the finnedtube heat exchanger, the cost ratio is about onefifth. The cost advantage is due to high rates of heat transfer and the ability to use materials other than high alloys to contain the salt.

\section{Future Research}

Future research should be directed toward experimentally determining the effects of packing size and type since, in lieu of such data, one must project these effects based on mass transfer data. Since the heat and mass transfer mechanisms are different, that approach is not satisfactory. At high temperatures, radiation heat transfer will become important. Thus, testing at high temperatures, perhaps with internally insulated columns, w11l be important.

To ultimately produce heat-transfer correlations that are valid over a wide range of operating conditions and useful for design purposes, it is necessary to understand the mechanisms of heat transfer. This is best carried out by fundamental studies almed at separating the effects of radiation, fin-effect, packing wetting, etc. Any experIment of heat transfer research at high temperatures $\left(>600^{\circ} \mathrm{C}\right)$ ust be delayed until materials research has identifled compatible heat tzansfer salts and containment materials.

\section{REYRRPNCES}

1. Bohn, M. S., Afr/Molten Salt Direct-Contact Heat Transfer Experiments and Economic Analysis, SERI/TR-252-2015, Golden, Colo., 1983.

2. Dubberly, L. J., Gormely, J. E., Kockman, J. A., Lang, W. R., and McKenzle, A. W., Cost and Performance of Thermal Storage Concepts in Solar Thermal Systems, SERI/TR-XP-0-9001-1-B; Golden, Colo., 1981.

3. Falr, J. R., "Designing Direct Contact Coolers/ Condensers," Chemlcal Engineertng, pp. 91-100, June 1972 .

4. Kays, W. M., and Londen, A. Lo, Compact Heat Exchangers, McGraw Hill Book Co., New York, 1964.

5. Krelth, F., Princlples of heat Transfer, Intext Publishing, New York, 1976.

6. Martin Marletta, "Internally. Insulated Thermal Storage System Development Program," MCR79-1369, Martin Marletta Aerospace Corp., Denver, Colo., 1979.

7. Norton Chenical Company, "Design Inforaztion for Packed Towers, Bulletin DC-11, Akron, Ohio, 1977.

8. Peters, $M_{0}$, and Timmerhaus, K., Plant Design and Economics for Chemlcal Engineers, McGraw H111 Book Co., New York, 198C.

9. Physical Properties Data Compilations Relevant to Energy Storage, II, "Molten Salts Data on Single and Multi-Component Salt Systems," NSRDSNBS 61, Part II.

10. Tortorell1, P. F., and DeVan, J. H., Thermal Convection Loop Study of the Corrosion of $\mathrm{Fe}$ $\mathrm{N1-Cr}$ Alloys by Molten $\mathrm{NaNO}_{2}-\mathrm{KNO}_{2}$ ORNL/TY-8298; Oak Ridge National Laboratory, Cak RIdge, Tenn., 1982. 